\title{
VARIASI KUAT MEDAN MAGNET DAN DAYA LISTRIK INPUT TERHADAP KARAKTERISTIK MOTOR LISTRIK DC DUA KUTUB
}

\author{
Karim $^{1}$, Ishak Semuel Erari ${ }^{2}$, Abdul Muis Muslimin ${ }^{3}$ \\ ${ }^{1,2,3}$ Prodi Fisika Jurusan Fisika FMIPA UNIPA \\ email: 1).karimimbeisika95@gmail.com,2).ishakerari@yahoo.com, \\ 3).a.muslimin@unipa.ac.id
}

\begin{abstract}
ABSTRAK
Penelitian tentang variasi medan magnet dan daya listrik input terhadap karakteristik motor listrik DC bertujuan untuk mengetahui pengaruh kuat medan magnet dan pengaruh besar daya listrik input terhadap RPM, efisiensi, dan torsi motor listrik DC serta mengetahui pengaruh kuat medan magnet permanen terhadap daya listrik input. Penelitian ini merupakan penelitian eksperimen, yang dimulai dengan pembuatan alat, pengambilan data, kemudian pengolahan data. Dalam pengambilan data, data yang diukur adalah tegangan listrik input, tegangan listrik output, arus listrik input, arus listrik output dan RPM. Hasil dari pengolahan data diperoleh bahwa setiap penambahan jumlah magnet akan menyebabkan RPM meningkat, daya listrik menurun, torsi menurun, dan efisiensi yang paling tertinggi $80.564 \%$ pada jumlah satu magnet. Sedangkan setiap penambahan daya listrik input menyebabkan RPM meningkat, torsi meningkat, dan efisiensi tertinggi pada tegangan listrik power supply 12 Volt yaitu $83.366 \%$.
\end{abstract}

Kata kunci : Motor Listrik DC, Magnet Permanen, RPM 


\section{PENDAHULUAN}

Di era globalisasi ini sebagian besar peralatan menggunakan energi listrik, sehingga konsumsi bahan bakar fosil untuk pembangkit listrik semakin meningkat. Peramalan konsumsi bahan bakar minyak di dalam negeri dari tahun 2014 mengalami peningkatan sampai tahun 2025 yaitu dari 396.214 ribu barel sampai 647.301 ribu barel (Sa'adah, Fauzi dan Juanda, 2017). Penggunaan bahan bakar fosil adalah sumber utama dari karbondioksida dan gas lain yang merupakan gas rumah kaca yang memberikan efek rumah kaca. Salah satu cara untuk mengurangi gas rumah kaca yaitu dengan mengurangi pemakaian energi listrik dalam peralatan yang memanfaatkan energi listrik, diantaranya adalah motor listrik.

Motor listrik merupakan perangkat elektromagnetis yang mengubah energi listrik menjadi energi mekanik (Raikhani, 2015). Energi mekanik yang dihasilkan berasal dari putaran rotor pada motor tersebut. Satuan dari putaran motor listrik adalah rpm (revolusi per menit). Secara umum motor listrik dapat dibedakan menjadi dua yaitu motor listrik AC (alternating current) dan motor listrik DC (direct current).

Motor listrik DC bekerja berdasarkan prinsip interaksi antara dua fluks magnetik. Ketika kumparan medan dan kumparan jangkar dihubungkan dengan suatu sumber tegangan DC maka pada kumparan medan akan mengalir arus medan sedangkan pada kumparan jangkar menghasilkan arus jangkar. Pada kumparan medan akan menghasilkan fluks magnet yang arahnya dari kutub utara menuju kutub selatan. Besar medan magnet bergantung pada besar arus listrik yang masuk dan jumlah lilitan pada kumparan medan tersebut. Konduktor pada jangkar yang berarus listrik akan menimbulkan fluks magnet yang melingkar. Fluks jangkar ini akan memotong fluks dari kumparan medan sehingga menyebabkan perubahan kerapatan fluks dari medan utamanya. Sesuai dengan hukum Lorentz, interaksi pada kedua fluks magnet akan menimbulkan suatu gaya mekanik pada konduktor jangkar yang disebut gaya Lorentz, yang nilainya adalah kerapatan fluks magnetik dikali arus listrik yang mengalir pada konduktor serta dikali dengan panjang konduktor (Putra dan Dinzi, 2014).

Putaran rotor motor listrik DC bergantung pada kuat medan magnet yang dihasilkan oleh kumparan medan dan besar arus listrik yang mengalir pada kumparan jangkar. Jika semakin besar medan magnet pada kumparan medan atau semakin besar arus listrik yang masuk pada kumparan jangkar maka energi mekanik yang dihasilkan semakin besar. Akan tetapi menurut Tipler (2001) karena kumpuran dalam hal ini kumparan jangkar berputar dalam medan magnet maka akan membangkitkan ggl induksi yang cenderung melawan ggl yang menyalurkan arusnya (arus pada jangkar). Ketika pertama kali motor berputar, tidak ada ggl induksi dan arusnya sangat besar, namun begitu motor mulai berputar ggl induksi meningkat dan arus listrik turun.

Magnet permanen adalah magnet yang menghasilkan kuat medan magnet sendiri, tanpa memerlukan energi dari luar untuk menghasilkan daya magnetnya. Magnet permanen memiliki sifat kemagnetan yang cukup lama, selain itu juga ramah lingkungan. Menurut Budiman dkk (2012), energi magnet yang dihasilkan oleh magnet permanen dapat berlangsung hingga 400 tahun. Oleh karena itu, magnet permanen akan menjadi solusi untuk 
mengurangi pemakaian energi listrik pada motor listrik dengan menggantikan medan magnet yang dihasilkan oleh arus listrik pada motor dengan magnet permanen itu sendiri.

Kuat medan magnet pada magnet permanen sangat berpengaruh penting di dalam penggunaanya pada generator maupun motor listrik. Menurut Jaya dkk (2017), pada penelitiannya tentang analisis perbandingan magnet neodymium dan magnet ferite untuk penerapan generator. Menemukan bahwa tegangan AC keluaran generator menggunakan magnet neodymium lebih besar dibandingkan dengan tegangan AC keluaran generator menggunakan magnet ferite. Hal itu disebabkan karena kuat medan magnet neodymium lebih kuat dari pada magnet ferite itu sendiri.

Melihat bagaimana pengaruh kuat medan magnet pada magnet permanen di dalam motor listrik maka peneliti akan melakukan penelitian tentang variasi medan magnet daya listrik input terhadap karakteristik motor listrik DC dua kutub dengan mengganti kumparan medan magnet yang dihasilkan oleh arus listrik menggunakan magnet permanen. Jumlah magnet permanen yang digunakan akan divariasikan.

\section{METODE PENELITIAN}

Penelitian ini dilakukan di Laboratorium Fisika FMIPA Universitas Papua (UNIPA) selama 20 bulan dengan rancangan percobaan sebagai berikut:

1. Jumlah magnet permanen 1, 2, 3, 4 dan 5 magnet sebagai stator.

2. Besar arus listrik input yang bergantung pada besar tegangan DC dari catu daya yaitu: 4 volt, 6 volt, 8 volt, 10 volt dan 12 volt.

Variabel yang di ukur dalam penelitian adalah arus listrik input, arus listrik output, tegangan listrik input, tegangan listrik output dan kecepatan rotasi motor (rpm) setiap variasi jumlah magnet maupun besar arus listrik input yang bergantun pada catu daya. Pemasangan alat ukur dapat dilihat pada Gambar 1.

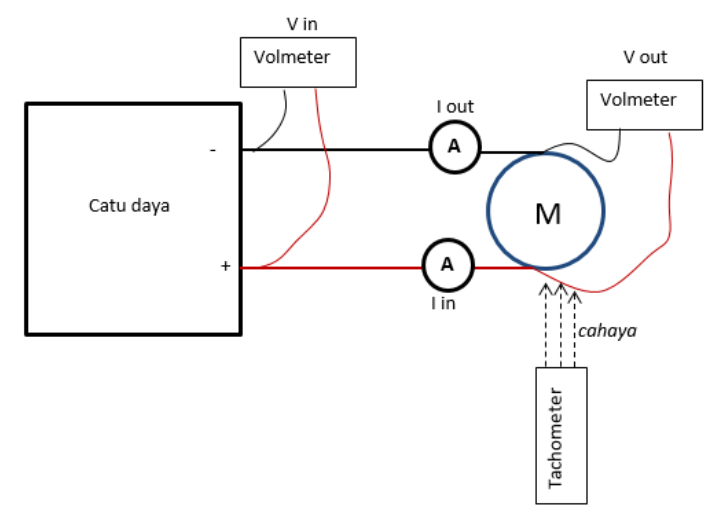

Gambar 1. Rangkain pemasangan alat ukur

Data arus listrik dan tegangan listrik akan digunakan untuk menghitung daya dan efisisensi motor listrik. Sedangkan tegangan output, arus listrik input dan RPM motor digunakan untuk menghitung nilai torsi $(\tau)$.

Daya input dan daya output dihitung menggunakan rumus

$$
\begin{gathered}
P_{\text {in }}=V_{\text {in }} \times I_{\text {in }} \text { dan } \\
P_{\text {out }}=V_{\text {out }} \times I_{\text {out }}
\end{gathered}
$$

Dimana:

$$
\begin{aligned}
& P_{\text {in }}=\text { daya input (Watt) } \\
& V_{\text {in }}=\text { tegangan input (Volt) } \\
& I_{\text {in }}=\text { arus input }=\text { arus jangkar } \\
& \quad \text { (Ampere) } \\
& P_{\text {out }}=\text { daya output (Watt) } \\
& V_{\text {out }}=\text { tegangan listrik output }= \\
& \quad \text { tegangan jangkar (Volt) } \\
& I_{\text {out }}=\text { arus output (Ampere) }
\end{aligned}
$$

Efisiensi motor listrik dapat dihitung menggunakan rumus

$$
\text { Efisiensi }(\eta)=\frac{P_{\text {out }}}{P_{\text {in }}} \times 100 \%
$$


Menurut Yuski dkk (2013) dan Suyanto (2016) torsi jangkar dapat ditentukan dengan persamaan dibawah ini.

$$
\tau=\frac{60 \times V_{a} I_{a}}{2 \pi N}
$$

Dimana:

$$
\begin{aligned}
\tau & =\text { torsi dalam satuan } \\
& \text { Newtonmeter (Nm) } \\
V_{a}= & \text { tegangan jangkar (Volt) } \\
I_{a}= & \text { arus jangkar (Ampere) } \\
N \quad= & \text { kecepatan putaran motor } \\
& \text { (rpm) }
\end{aligned}
$$

Hubungan diantara variabel pengamatan akan ditampilkan di dalam bentuk grafik menggunakan aplikasi microsoft excel.

\section{HASIL PENELITIAN}

Pada penelitian ini yang dilihat adalah pengaruh perubahan besar daya listrik input yang masuk pada jangkar rotor dan pengaruh perubahan besar medan magnet sebagai stator pada motor listrik DC dengan variasi jumlah magnet yaitu: 1 magnet, 2 magnet, 3 magnet, 4 magnet dan 5 magnet. Jarak antara magnet dengan kumparan jangkar adalah sejauh $2,5 \mathrm{~cm}$. Adapun besar medan magnet setiap variasi jumlah magnet adalah seperti Tabel 1 .

Tabel 1 Nilai besar medan magnet setiap variasi jumlah magnet

\begin{tabular}{ccc}
\hline No. & $\sum$ Magnet & Besar medan (mT) \\
\hline 1 & 1 & 35,04 \\
2 & 2 & 44,76 \\
3 & 3 & 49,51 \\
4 & 4 & 54,73 \\
5 & 5 & 58,79
\end{tabular}

Setiap variasi jumlah magnet akan divariasi besar tegangan listrik yang masuk pada jangkar $\left(\mathrm{V}_{\text {in }}\right)$ dengan memvariasi tegangan yang tertera di power supply $\left(\mathrm{V}_{\mathrm{ps}}\right)$ yaitu: 4 volt, 6 volt, 8 volt, 10 volt, dan 12 volt. Untuk magnet ke-1 menggunakan magnet batangan sedangkan magnet ke-2 sampai ke-5 menggunakan magnet ring. Pengambilan data dilakukan pada saat rotor motor berputar.
Arus listrik yang digunakan pada penelitian ini berasal dari power supply dengan memvariasi tegangan listriknya. Adapun hubungan arus listrik input dengan tegangan input dapat dilihat dari pada Gambar 2.

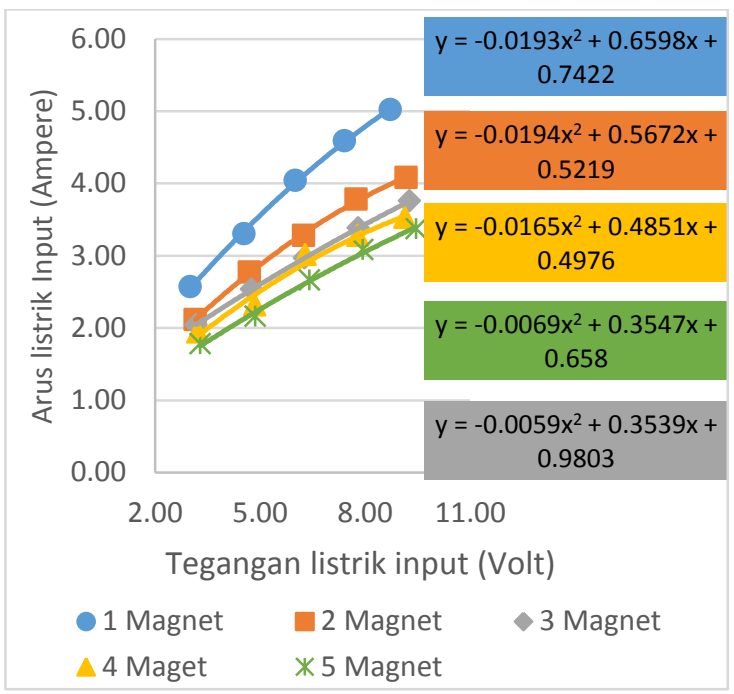

Gambar 2. Hubungan Tegangan listrik input dan arus listrik input

Dari Gambar 2, setiap kenaikan tegangan listrik input maka arus listrik juga ikut naik. Namun setiap penambahan jumlah magnet arus listrik input juga ikut menurun. Semakin sedikit jumlah magnet, kemiringan grafik semakin curam. Hal itu disebakan karena perubahan arus listrik input yang semakin tiinggi setiap perubahan tegangan listrik input.

\section{Putaran Motor Listrik (RPM)}

\section{a. Hubungan daya listrik input dengan RPM}

Kecepatan motor listrik magnet permanen berbanding langsung dengan tegangan listrik yang diberikan pada jangkar. Semakin besar tegangan pada jangkar maka semakin tinggi kecepatan yang dihasilkan oleh motor (Frank, 1996 dalam Kumalasari, 2019).

Menurut Sunarti (2018) menyebutkan bahwa pengaruh arus jangkar atau arus yang masuk pada jangkar berbanding lurus dengan kecepatan 
putaran motor listrik. Semakin besar arus yang masuk pada jangkar maka semakin besar pula kecepatan putaran rotor pada motor DC tersebut.

Diketahui bahwa daya listrik merupakan perkalian antara tegangan listrik dan arus listrik, maka dari pernyataan di atas disimpulkan bahwa kecepatan putaran motor berbanding lurus dengan daya listrik input. Sehingga semakin besar daya listrik input yang masuk pada motor DC maka semakin besar RPM yang dihasilkan oleh motor listrik DC.

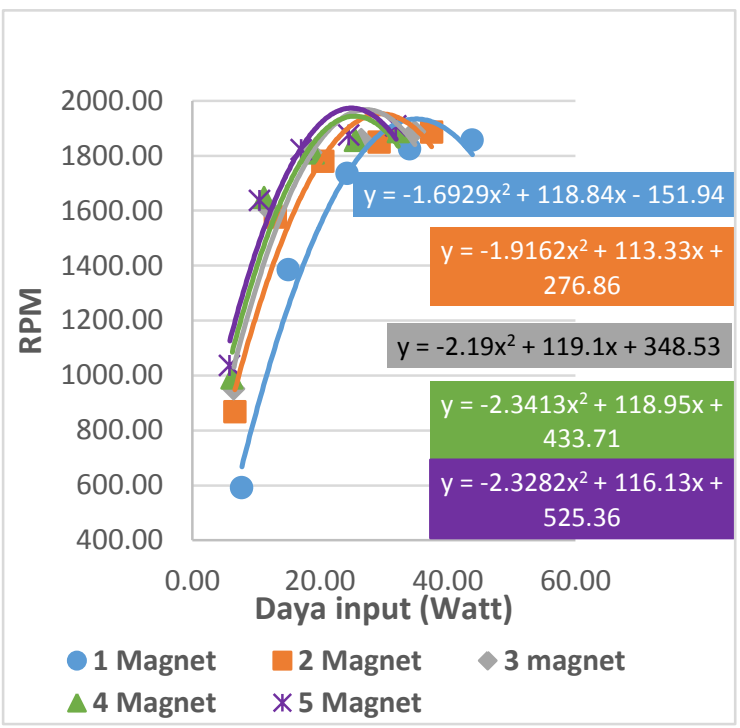

Gambar 3.Hubungan antara daya listrik input dan RPM

Dari Gambar 3 terlihat jelas bahwa setiap kenaikan daya listrik input yang masuk pada jangkar motor mengalami kenaikan RPM, baik pada 1 magnet maupn jumlah 2 magnet, 3 magnet, dan 4 magnet dan 5 magnet. Misalkan pada jumlah 1 magnet, mula-mula daya listrik input yang masuk pada jangkar adalah sebesar 7,74 watt sehingga memperoleh RPM sebesar 590,39. Kemudian daya input listriknya dinaikan sebesar 15,02 Watt sehingga motor listrik mengalami kenaikan RPM sebesar 1384,11 . Ketika daya input listrik dinaikan sampai 43,84 Watt diperoleh RPM motor listrik sebesar 1856,28. Meskipun setiap penambahan jumlah magnet RPM meningkat tetapi pada grafik untuk variasi jumlah 1 magnet dapat dilihat bahwa, ketika daya listrik input mendekati 30 Watt, RPM listrik sudah mulai konstan. Artinya RPM motor listrik mengalami perubahan yang sangat kecil ketika daya listrik inputnya dinaikan diatas 30 Watt. Sedangkan untuk variasi jumlah 2 magnet sampai 5 magnet, RPM mulai konstan daya listrik input mendekati 25 Watt.

Perubahan meningkatnya kecepatan putaran motor listrik setiap penambahan daya listrik input, karena arus listrik yang masuk pada kumparan rotor meningkat. Arus listrik itu sendiri berbanding lurus dengan RPM motor listrik. Setiap meningkatnya arus listrik yang masuk pada kumparan jangkar akan menyebabkan kumparan jangkar memiliki penambahan gaya putar yang lebih besar, sehingga motor lebih mudah untuk berpuatar. Meningkatnya RPM motor setiap bertambahnya daya listrik dialami juga oleh Adam (2011) di dalam penelitiannya. Ia menemukan bahwa disaat daya listrik 112 Watt menghasilkan putaran motor listrik sebesar 1000 RPM. Kemudian daya listrik dinaikan menjadi 158 Watt, kecepatan putaran motor listrik bertambah sampai 3100 RPM. Dengan demikian dapat dikatakan bahwa daya listrik berbanding lurus dengan kecepatan putaran motor listrik.

\section{b. Hubungan Antara Besar Medan Magnet Permanen Terhadap RPM}

Menurut Muhamad Arfan (2013) dalam Pattiapon dkk (2019) bahwa kecepatan motor listrik dapat diatur dengan mengubah nilai arus medan. Kenaikan arus medan sebanding dengan kenaikan kecepatan putaran motor. Arus medan sebanding dengan besarnya medan magnet pada kumparan medan. Jadi dengan demikian kecepatan putaran motor listrik berbanding lurus dengan medan magnet pada rotor. 
Untuk melihat hubungan besar medan magnet terhadap RPM yang dibuat tetap adalah besar tegangan listrik pada power supply dan yang divariasi adalah jumlah magnet. Setiap penambahan jumlah magnet memberikan peningkatan besar medan pada stator motor listrik yang dapat dilihat pada tabel 1. Adapun RPM yang dihasilkan setiap penambahan jumlah magnet dapat dilihat pada Gambar 4

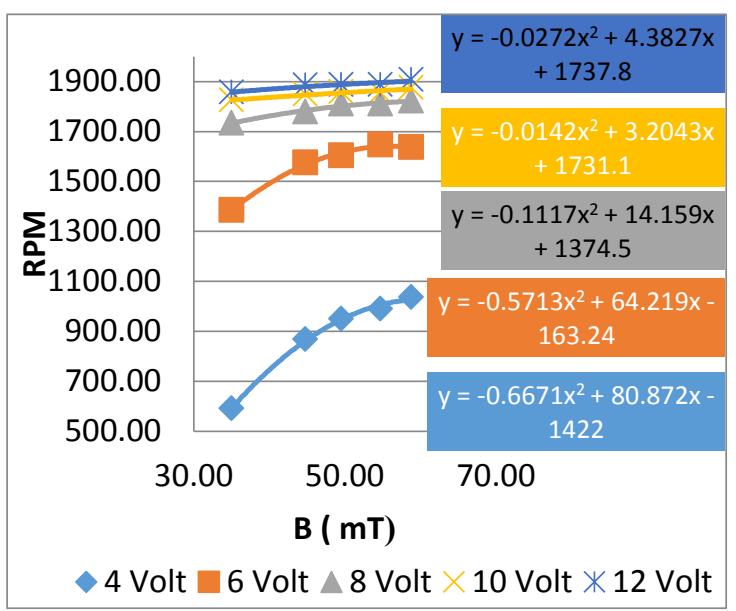

Gambar 4. 1 Hubungan antara medan magnet permanen dengan RPM.

Pada Gambar 4 hubungan besar medan magnet permanen dengan RPM dapat dilihat bahwa, untuk tegangan listrik 4 Volt RPM terus meningkat sampai pada variasi jumlah 4 magnet $(57,73 \mathrm{mT})$, sedangakan pada variasi 5 magnet $(58,79$ mT) RPM motor listrik sudah mulai konstan atau motor mengalami perubahan RPM yang sangat kecil. Pada tegangan listrik 6 Volt, RPM terus meningkat sampai pada variasi jumlah 3 magnet (49,51 mT) dan pada variasi jumlah 4 magnet sampai 5 magnet RPM cenderung konstan. Pada tegangan listrik 8 Volt sampai 12 Volt, motor listrik memiliki nilai RPM yang cenderung konstan ketika divariasi jumlah magnetnya.

Penggunaan magnet permanen sebagai stator oleh motor listrik DC, motor listrik tidak memerlukan arus listrik lagi untuk membangkitkan medan magnet pada stator. Sehinga ketika sumber listrik dihubungkan pada motor listrik, sumber listrik tersebut hanya digunakan pada kumparan jangkar. Ketika arus listrik mengalir pada kumparan jangkar di dalam medan magnet stator maka akan membangkitkan gaya putar pada jangkar. Gaya putar ini nilainya berbanding lurus dengan medan magnet pada stator dan arus listrik yang masuk pada jangkar atau pada rotor. Sehingga ketika medan magnet dinaikan maka motor memiliki gaya awal untuk berputar semakin besar, akibatnya RPM yang dihasilkan oleh motor juga besar. Pada penelitian ini perubahan medan magnet tidak terjadi secara spontan (merubah medan magnet saat motor dalam kondisi putaran normal pada medan magnet tertentu) tetapi perubahan medan magnet dilakukan setelah motor dalam keadaan diam.

Dalam kasus penggunaan magnet permanen sebagai stator ini, prinsipnya adalah nilai medan magnet konstan sehingga ketika motor berputar medan magnet tidak berubah, yang berubah adalah hanya nilai arus listrik pada jangkar. Sehingga pada saat motor berputar untuk menaikan RPM, kita hanya mengubah nilai arus yang masuk pada jangkar. Jika hasil yang didapat dibandingkan dengan penelitian Ananda dkk (2003) tentang karakteristik motor DC penguat luar terhadap posisi sikat. Mereka menemukan bahwa RPM merupakan fungsi dari arus listrik medan. RPM meningkat disaat arus listrik medan (Im) menurun. Misalkan hasil peneltianya di posisi sikat $0^{\circ}$, ketika Im sama dengan 1,80 A maka putaran motor sebesar 2204 dan setelah Im turun menjadi 1,70 A motor menghasilkan putaran sebesar 2232 RPM. Dari hasil yang mereka dapat, untuk meningkatkan RPM bisa dilakukan dengan menurunkan arus listrik medan. Dengan kata lain mereka menurunkan medan magnet pada kumparan medan akan meningkatkan nilai RPM. Sedangkan meningkatnya RPM setiap penambahan medan magnet dalam penelitian ini, disebabkan karena mengganti medan 
magnet saat motor dalam keadaan diam. Sehingga setiap penambahan jumlah magnet akan memberikan gaya awal yang memutar berbeda-beda pula. Semakin besar medan magnetnya gaya putarnya juga semakin besar pada awalan putaran rotor, sehingga RPM yang dihasilkan juga meningkat.

\section{Daya Listrik}

\section{a. Pengaruh Perubahan Tegangan Catu Daya Terhadap Daya Listrik Input}

Perubahan tegangan listrik pada power supply dari 4 volt, 6 volt, 8 volt, 10 volt, dan 12 berpengaruh besar pada arus listrik pada motor listrik. Setiap tegangan listrik dinaikan akan menyebabkan kenaikan arus listrik input pada motor listrik. Sehingga daya listrik input yang masuk pada motor listrik juga meningkat. Hal itu dapat dilihat pada Gambar 5.

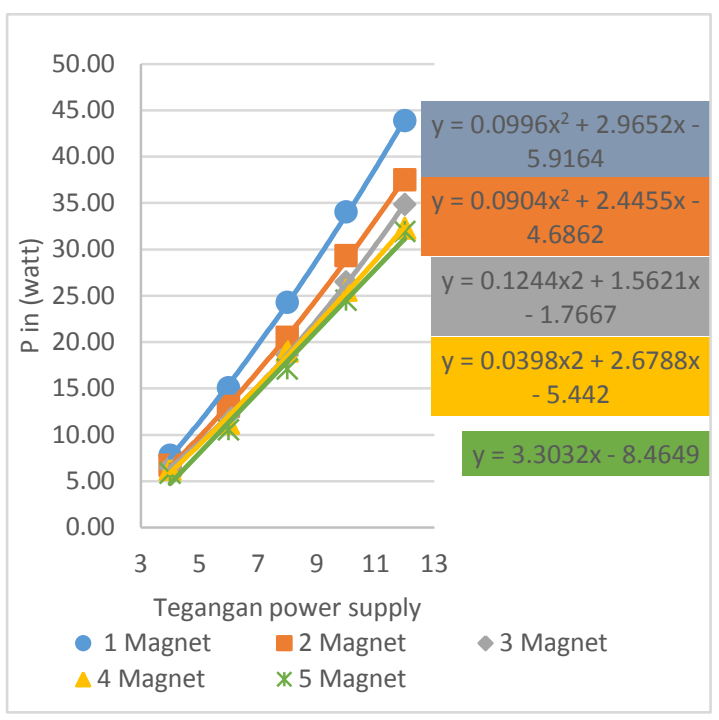

Gambar 5. Pengaruh perubahan tegangan power supply terhadap daya input

Dari Gambar 5, dapat dilihat setiap penambahan jumlah tegangan listrik pada power supply menyebabkan kenaikan daya input yang masuk pada motor listrik. Misalkan pada jumlah 1 magnet ketika tegangan power supplai 4 volt, maka menghasilkan $V_{\text {in }} 3,01$ volt arusnya 2,57 Ampere sehingga daya listrik input sebesar 7,74 Watt. Pada tegangan power supply 6 volt, menghasilkan Vin sebesar 4,55 volt sedangkan $\mathrm{I}_{\text {in }}$ adalah 3,30 Ampere sehinggga daya listrik input yang dihasilkan sebesar 15,02 Watt. Kemudian teganngan power supplay dinaikan 6 volt maka menghasilkan $V_{\text {in }}$ sebesar 6,01 volt dan $\mathrm{I}_{\text {in }}$ sebesar 4,40 sehingga daya input yang dihasilkan 24,27 Watt. Pada tegangan power supply 10 volt nilai $\mathrm{V}_{\text {in }}$ sebesar 7,42 Volt sedangkan $\mathrm{I}_{\text {in }}$ 4,59 Ampere maka menghasilkan daya listrik input sebesar 34,03 Watt. Sedangkan pada tegangan power supply 12 Volt nilai $\mathrm{V}_{\text {in }}$ adalah 8,73 Volt sedangakan nilai $I_{\text {in }}$ sebesar 5,43 Ampere, maka menghasilkan daya listrik sebesar 43,84 Watt.

Naiknya daya listrik input setiap kenaikan tegangan listrik pada power supply disebabkan karena arus listrik input bergantungpada pada besarnya nilai tegangan listrik pada power supply. Semakin besar kenaikan tegangan listrik pada power supply maka arus listrik juga meningkat. Akibatnya daya listrik yang akan masuk pada kumparan jangkar ikut meningkat. Penigkatan tegangan listrik menyebabkan kenaikan daya listrik diperoleh juga oleh Susanto (2017), bahwa saat tegangan listrik 75 Volt maka arus listriknya sebesar 0,24 Ampere, maka daya listrik yang menghasilkan sebesar 28 Watt. Kemudian tegangan listrik dinaikan 125 Volt, arus listriknya menjadi 0,34 volt dan daya listrik naik menjadi 76 Watt. Dengan demikian dapat dikatakan setiap kenaikan sumber tegangan maka akan mengakibatkan kanaikan arus listrik dan daya listrik meningkat.

\section{b. Pengaruh Perubahan Tegangan Input Terhadap Daya Listrik Output}

Daya listrik output dalam penelitian ini adalah sisa dari daya listrik input karena sudah dipakai oleh kumparan jangkar, bukan daya listrik yang kembali dihasilkan 
oleh motor listrik itu sendiri. Sehingga setiap kenaikan tegangan listrik pada power supply juga berpengaruh pada daya listrik out tersebut. Hubungan antara tegangan listrik power supply dengan daya listrik output dapat dilihat pada Gambar 6.

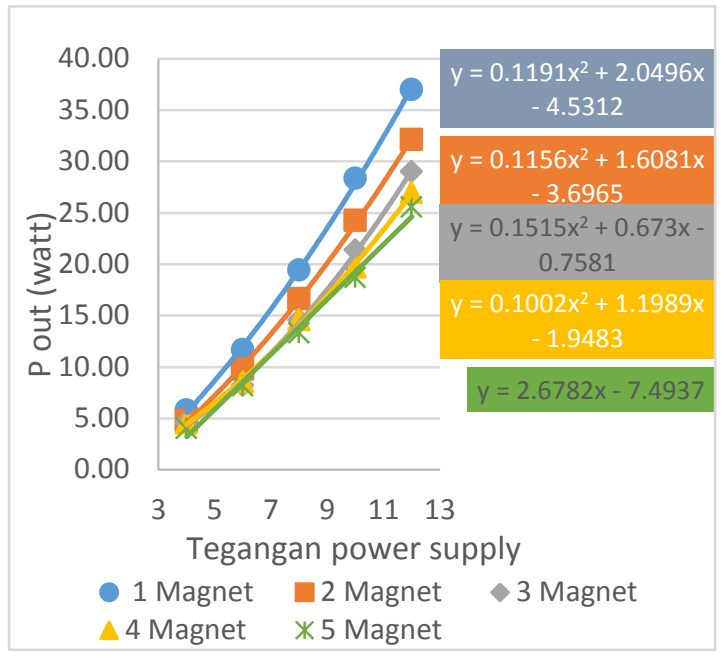

Gambar 6. Pengaruh perubahan tegangan power supply terhadap daya listrik output

Dari gambar 6 di atas dapat dilihat bahwa daya listrik output meningkat jika tegangan listrik pada power supply dinaikan. Namun jika dibandingkan dengan daya listrik input, daya listrik output lebih kecil daripada daya listrik input.

Hal itu terjadi karena sebagian daya listrik terkonversi dalam bentuk energi lain. Sehingga menyebakan penggurangan daya listrik. Dan salah satu penyebab berkuranngnya daya listrik karena terjadi rugi-rugi pada motor listrik seperti rugi tembaga, rugi sikat dll. Nilai daya listrik output lebih kecil dari daya listrik input juga diperoleh Suyanto (2016). Ia menemukan bahwa pada tegangan listrik 220 volt, nilai daya listrik input sebesar 145,2 Watt sedangkan daya listrik outputnya hanya 53,8 Watt setealah dikurangi nilai rugi-rugi.

\section{c. Pengaruh Perubahan Medan Magnet Permanen Terhadap Arus Listrik Input}

Hubungan antara arus jangkar dengan medan magnet dapat dilihat pada Gambar 7.

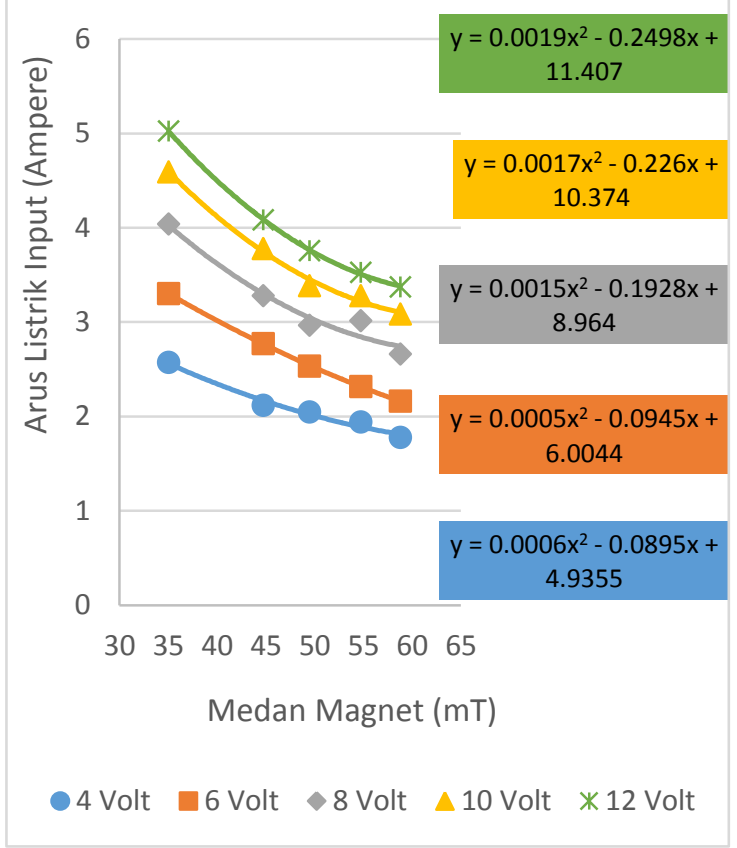

Gambar 7. Hubungan antara medan magnet dan arus listrik

Dari gambar 7 dapat dilihat bahwa setiap penambahan jumlah magnet yang menyebabkan medan magnet meningkat pada stator motor listrik akan menurunkan nilai arus listrik yang masuk pada jangkar. Hal itu disebabkan karena terdapat perubahan fluks akibat adanya medan magnet yang melewati simpal jangkar sehingga menimbulkan arus induksi. Arus induksi ini sejalan dengan meningkatnya RPM. Menurut Rijono (1977) arus induksi ini berlawanan arah dengan arus input atau arus yang masuk pada jangkar. Hal ini yang menyebabkan bertambahnya medan magnet arus listrik input berkurang. 


\section{d. Pengaruh Perubahan Medan Magnet Permanen Terhadap Daya Listrik Input}

Adapun hubungan antara daya listrik input dengan besar medan magnet permanen dapat dilihat pada Gambar 8

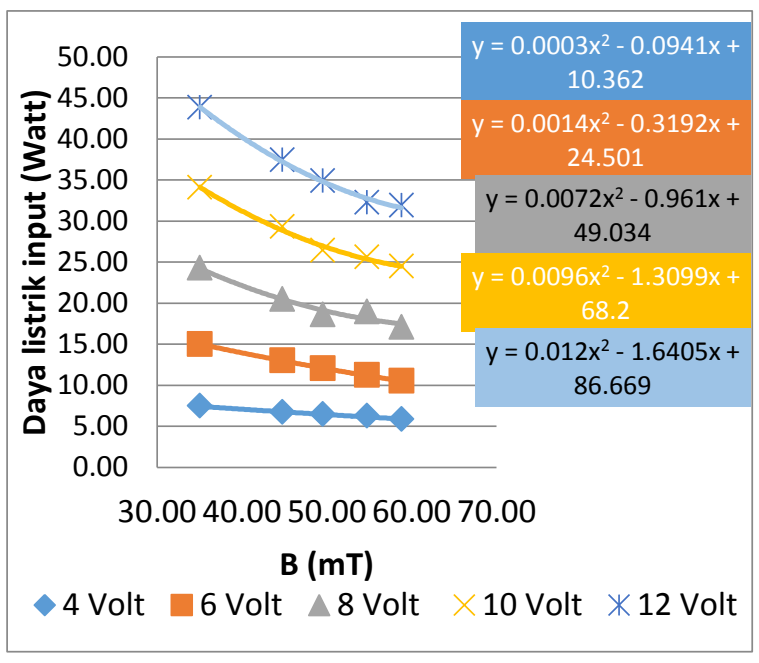

Gambar 8. Hubungan jumlah magnet dan daya listrik input

Dari Gambar 8, dapat dilihat bahwa setiap kenaikan medan magnet, maka daya listrik input yang diperlukan oleh motor nilainya menurun. Pada tegangan 4 volt disaat jumlah 1 magnet $(35,04 \mathrm{mT})$ daya listrik input mencapai 7,47 watt dan ketika ditambahkan jumlah magnet sampai 5 magnet dengan medan magnet sebesar $(58,79 \mathrm{mT})$ maka daya listrik input menurun hingga 5,85 watt yang dapat di lihat pada lampiran 2. Untuk 6 volt pada saat 1 magnet daya listrik inputnya 15,2 watt sedangkan pada saat 5 magnet daya listrik inputnya menurun sampai 10,51. Pada tegangan 8 volt pada saat 1 magnet daya listrik inputnya mencapai 24,28 watt sedangkan pada jumlah 5 magnet daya listrik input turun 17,06 watt. Pada tegangan 10 volt di jumlah 1 magnet daya listrik input mencapai 34,06 watt sedangkan ketika magnet ditambahkan sampai jumlah 5 magnet daya listrik input turun hingga 24,28 watt. Pada tegangan 10 volt di jumlah 1 magnet daya listrik inputnya adalah 43,82 watt sedangkan pada saat jumlah 5 magnet daya listrik input turun hingga 31,90 watt. Dari grafik dapat dilihat semakin tinggi tegangan listrik power supply maka perubahan daya listrik input semakin menurun, yang dapat dalihat dari bentuk kemiringan bentuk grafik.

Penyebab terjadinya penurun daya input motor listrik karena setiap penambahan medan magnet akan menyebabkan meningkatnya RPM. Meningkatnya nilai RPM ini mengakibatkan penurunan arus listrik yang masuk pada kumparan jangkar. RPM itu sendiri berpengaruh pada arus yang masuk pada jangkar. Hal ini sesuai menurut Tipler (2001) ketika RPM meningkat akan menimbulkan peningkatan ggl induksi oleh motor yang menyebabkan penurunan arus yang masuk pada jangkar. Sehingga untuk peningkatan medan magnet pada rotor memberikan manfaat dapat mengurangi daya listrik yang masuk pada motor.

\section{e. Pengaruh Perubahan Medan Magnet Permanen Terhadap Daya Listrik Output}

Setiap penambahan jumlah medan magnet, selain menyebabkan daya listrik input turun juga menyebakan daya listrik output pada motor juga menurun. Grafik hubungan antara medan magnet dengan daya listrik output dapat diliihat pada Gambar 9

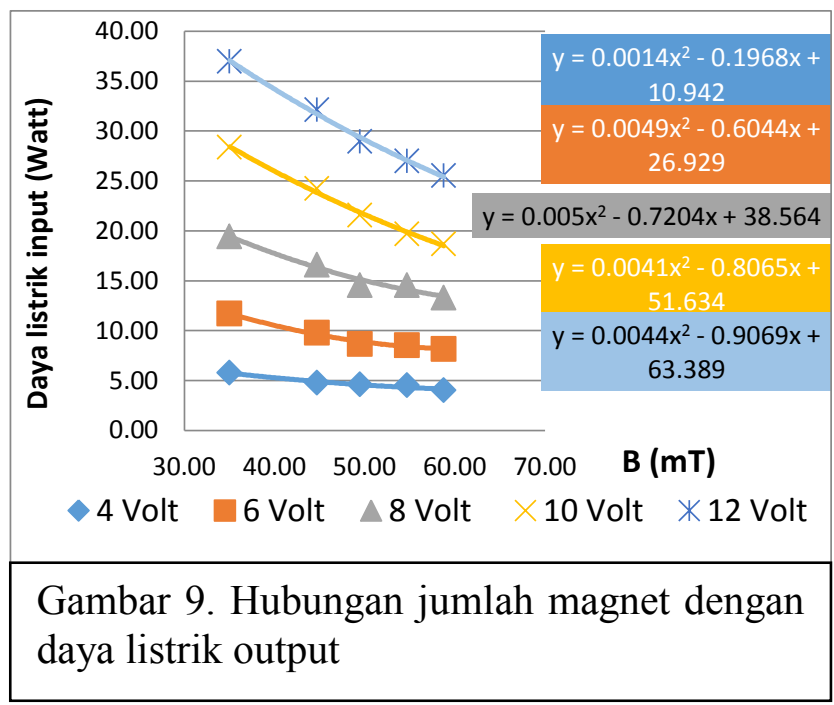


Dari Gambar 9 dapat dilihat bentuk grafik daya listrik output terhadap perubahan jumlah magnet memiliki pola yang sama dengan daya listrik input terhadap perubahan jumlah magnet. Daya listrik output maupun daya listrik input nilainya turun setiap penambahan jumlah magnet atau setiap kenaikan besar medan magnet. Namun daya listrik output lebih kecil daripada daya listrik input.

Daya listrik output lebih kecil dari daya listrik input karena terjadi rugi-rugi daya listrik setiap kenaikan medan magnet motor. Rugi- rugi tersebut yang akan mengurangi daya listrik yang pada kumparan jangkar. Perbedaan nilai daya listrik output dengan daya listrik input pada motor listrik juga dialami oleh Gunawan dkk (2000) di dalam penelitiannya. Mereka memperoleh nilai daya listrik input sebesar 6,69 Watt namun daya listrik outputnya turun 4,69 Watt. Hal itu terjadi karena setiap motor listrik memiliki nilai-rugi baik rugi jangkar, rugi sikat dan rugi-rugi yang lain.

\section{Efisiensi}

Efisiensi adalah daya listrik output dibagi daya listrik input dikali 100\% seperti yang ditunjukan pada persamaan 3 . Adapun besar efisiensi daya motor listrik ditunjukan pada Tabel 2 dan Tabel 3.

Tabel 2.Nilai rata-rata efisiensi daya listrik pada motor listrik per tegangan listrik power supply (catu daya).

\begin{tabular}{|c|c|c|c|c|}
\hline \multirow{2}{*}{ No. } & \multicolumn{2}{|c|}{ Tegangan } & \multirow[b]{2}{*}{$\begin{array}{c}\text { Efisiensi } \\
\text { (\%) }\end{array}$} & \multirow{2}{*}{$\begin{array}{c}\text { Nilai } \\
\text { Rata- } \\
\text { Rata } \\
(\%)\end{array}$} \\
\hline & $\begin{array}{l}\text { Catu } \\
\text { Daya } \\
\text { (Volt) }\end{array}$ & $\begin{array}{l}\text { Jumlah } \\
\text { Magnet }\end{array}$ & & \\
\hline \multirow{5}{*}{1} & \multirow{5}{*}{4} & 1 & 77.38 & \multirow{5}{*}{71.982} \\
\hline & & 2 & 71.04 & \\
\hline & & 3 & 70.72 & \\
\hline & & 4 & 72.32 & \\
\hline & & 5 & 68.45 & \\
\hline \multirow{5}{*}{2} & \multirow{5}{*}{6} & 1 & 77.83 & \multirow{5}{*}{75.668} \\
\hline & & 2 & 75.12 & \\
\hline & & 3 & 71.93 & \\
\hline & & 4 & 75.82 & \\
\hline & & 5 & 77.64 & \\
\hline
\end{tabular}

\begin{tabular}{ccccc}
\hline Lanjutan tabel 2 & & & \\
\hline No. $\begin{array}{c}\text { Tegangan } \\
\text { Catu } \\
\text { Daya } \\
\text { (Volt) }\end{array}$ & $\begin{array}{c}\text { Jumlah } \\
\text { Magnet }\end{array}$ & $\begin{array}{c}\text { Efisiensi } \\
\text { (\%) }\end{array}$ & $\begin{array}{c}\text { Nilai } \\
\text { Rata- } \\
\text { Rata } \\
\text { (\%) }\end{array}$ \\
\hline & & 1 & 79.98 & \\
& & 2 & 81.05 & \\
3 & 8 & 3 & 78.20 & 78.768 \\
& & 4 & 76.74 & \\
& & 5 & 77.87 & \\
\hline & & 1 & 83.26 & \\
4 & 10 & 2 & 82.66 & \\
& & 3 & 81.59 & 81.628 \\
& & 4 & 76.97 & \\
& & 5 & 83.66 & \\
& & 1 & 84.37 & \\
5 & 12 & 2 & 85.79 & \\
& & 3 & 82.98 & 83.366 \\
& & 4 & 83.66 & \\
& & 5 & 80.03 & \\
\hline
\end{tabular}

Dari Tabel 2, terlihat bahwa setiap penambahan tegangan listrik pada power supply, rata-rata efisiensi daya listrik mengalami peningkatan. Pada tegangan listrik 4 Volt efisiensi listrik yang diperoleh sebesar $71.982 \%$. Ketika tegangan listrik dinaikan 6 Volt efisiensi yang dihasilkan sebesar $75.668 \%$. Efisiensi yang tertinggi yang yaitu pada tegangan listrik 12 Volt sebesar $83.366 \%$. Tabel 2. Nilai rata-rata efisiensi daya listrik pada motor listrik per jumlah magnet

\begin{tabular}{|c|c|c|c|c|}
\hline \multirow[b]{2}{*}{ No. } & \multicolumn{3}{|c|}{ Tegangan } & \multirow{2}{*}{$\begin{array}{c}\text { Nilai } \\
\text { Rata- } \\
\text { Rata } \\
(\%)\end{array}$} \\
\hline & $\begin{array}{l}\text { Jumlah } \\
\text { Magnet }\end{array}$ & $\begin{array}{l}\text { Catu } \\
\text { Daya } \\
\text { (Volt) }\end{array}$ & $\begin{array}{c}\text { Efisiensi } \\
\text { (\%) }\end{array}$ & \\
\hline \multirow{5}{*}{1} & \multirow{5}{*}{1} & 4 & 77.38 & \multirow{5}{*}{80.564} \\
\hline & & 6 & 77.83 & \\
\hline & & 8 & 79.98 & \\
\hline & & 10 & 83.26 & \\
\hline & & 12 & 84.37 & \\
\hline \multirow{5}{*}{2} & \multirow{5}{*}{2} & 4 & 71.04 & \multirow{5}{*}{79.132} \\
\hline & & 6 & 75.12 & \\
\hline & & 8 & 81.05 & \\
\hline & & 10 & 82.66 & \\
\hline & & 12 & 85.79 & \\
\hline
\end{tabular}


Lanjutan tabel 3

\begin{tabular}{|c|c|c|c|c|c|c|}
\hline No. & \multicolumn{2}{|c|}{$\begin{array}{l}\text { Jumlah } \\
\text { Magnet }\end{array}$} & \multicolumn{2}{|c|}{$\begin{array}{c}\text { Tegangan } \\
\text { Catu Daya } \\
\text { (Volt) }\end{array}$} & $\begin{array}{c}\text { Efisie } \\
\text { nsi } \\
(\%)\end{array}$ & $\begin{array}{l}\text { Nila } \\
\text { i } \\
\text { Rat } \\
\text { a- } \\
\text { Rat } \\
\text { a } \\
\text { (\%) }\end{array}$ \\
\hline 3 & 3 & & $\begin{array}{c}4 \\
6 \\
8 \\
10 \\
12\end{array}$ & $\begin{array}{c}70.72 \\
71.93 \\
78.2 \\
81.59 \\
82.98\end{array}$ & \multicolumn{2}{|c|}{77.084} \\
\hline 4 & 4 & $\begin{array}{l}8 \\
1 \\
0 \\
1 \\
2\end{array}$ & $\begin{array}{c}72.3 \\
2 \\
75.8 \\
2 \\
76.7 \\
4 \\
76.9 \\
7 \\
83.6 \\
6\end{array}$ & & 77.102 & \\
\hline 5 & 5 & $\begin{array}{l}8 \\
1 \\
0 \\
1 \\
2\end{array}$ & $\begin{array}{c}68.4 \\
5 \\
77.6 \\
4 \\
77.8 \\
7 \\
83.6 \\
6 \\
80.0 \\
3\end{array}$ & & 77.53 & \\
\hline
\end{tabular}

Dari Tabel 3 dapat dilihat bahwa setiap penambahan jumlah magnet memperoleh efisiensi daya listrik rata-rata seluruh variasi tegangan listrik, berkisar antara $77.084 \%$ sampai $80.564 \%$. Efisensi yang tertinggi pada jumlah 1 magnet.

Nilai efisiensi daya listrik motor DC ini sangat dipengaruhi oleh nilai rugi-rugi pada motor tersebut. Semakin besar nilai rugi daya listrik pada motor listrik maka nilai keluaran motor tersebut akan semakin kecil, akibatnya nilai efisiensi motor listrik kecil. Semakin besar nilai efisiensi daya listrik yang dimiliki motor, maka motor tersebut semakin baik.

\section{Torsi \\ a. Pengaruh daya input terhadap torsi motor listrik}

Torsi yang ditinjau dalam penelitian ini adalah torsi jangkar. Torsi jangkar adalah torsi yang disebabkan oleh jangkar pada saat motor listrik berputar (Suyanto, 2016). Untuk melihat pengaruh daya listrik input terhadap torsi motor listrik yaitu dengan cara medan magnet dibuat tetap, sedangkan yang divariasi adalah tegangan yang masuk pada motor listrik. Adapun hubungan antara daya listrik input denngan torsi dapat dilihat pada Gambar 10

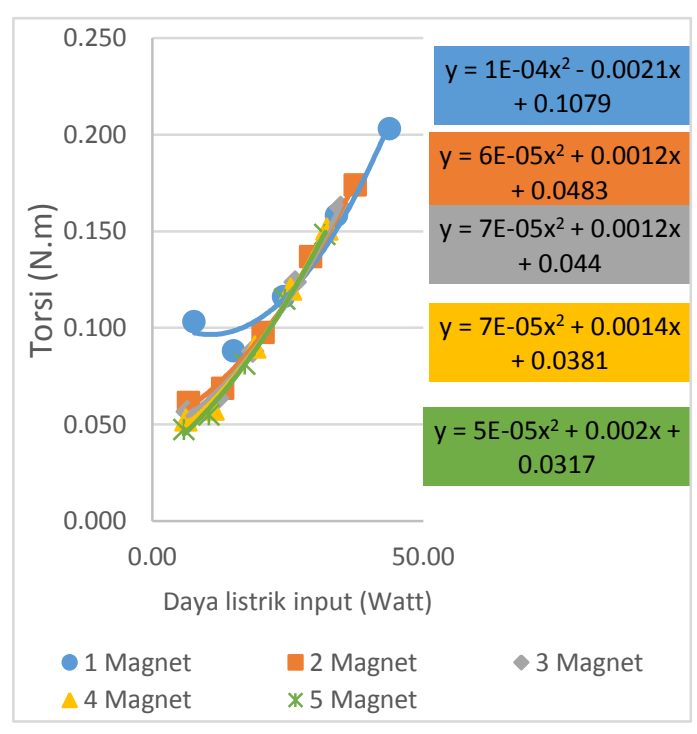

Gambar 10 Hubungan daya listrik input dengan torsi

Dari gambar 10 dapat dilihat bahwa setiap penambahan daya listrik input baik pada jumlah 1 magnet, 2 magnet, 3 magnet, 4 magnet maupun 5 magnet torsi motor naik. Kenaikan torsi setiap penambahan daya input listrik pada grafik di atas, disebabkan karena arus yang masuk pada jangkar juga meningkat 
seiring bertambahnya tegangan listrik pada power supply yang masuk ke kumparan jangkar. Torsi yang dihasilkan oleh motor listrik selalu berbanding lurus dengan nilai arus listrik dan tegangan yang masuk pada jangkar atau berbanding lurus dengan listrik . Hal yang sama juga diperoleh Saptono dkk (2018) pada penelitiannya. Mereka menemukan bahwa pada saat daya listrik 3,6 watt torsi motor sebesar 11,46 $\mathrm{Nm}$, kemudian setelah daya listrik naik menjadi 12,58 watt torsi sudah menjadi $21,85 \mathrm{Nm}$.

\section{b. Hubungan Antara Medan Magnet Permanen Dengan Torsi}

Untuk melihat hubungan pengaruh medan magnet terhadap torsi, yang divariasi adalah jumlah magnet dan yang dibuat tetap adalah tegangan power supply. Adapun pengaruh hubungan medan magnet terhadap torsi dapat dilihat pada Gambar 11.

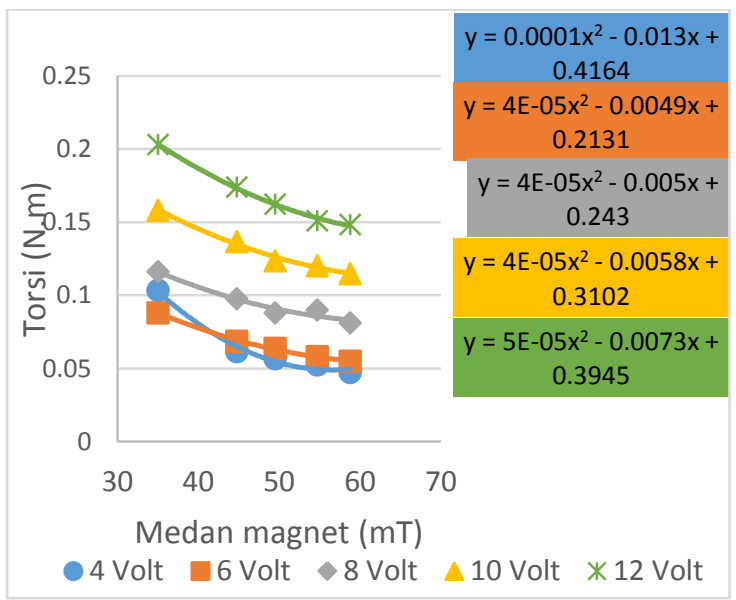

Gambar 11 Pengaruh perubahan medan magnet terhadap torsi

Dari grafik pada gambar 11 bahwa, setiap penambahan jumlah magnet menyebabkan penurunan torsi. Secara umum dapat dilihat bahwa rata-rata torsi yang nilainya besar berada pada jumlah 1 magnet $(35,04 \mathrm{mT})$. Misalkan pada tegangan 4 volt disaat jumlah 1 magnet torsi yang dihasilkan sebesar $0,103 \mathrm{Nm}$ sedangkan pada jumlah 5 magnet $(58,79)$ torsinya adalah $0,047 \mathrm{Nm}$. Dapat dilihat juga bahwa pada tegangan 6 volt di jumlah 1 magnet manghasilkan torsi sebesar 0,088 $\mathrm{Nm}$ sedangkan pada jumlah 5 magnet torsi yang dihasilkan sebesar 0,055 Nm. Pada tegangan 8 volt di jumlah 1 magnet torsinya sebesar $0,116 \mathrm{Nm}$ sedangkan ketika magnetnya ditambah sampai 5 magnet nilai torsinya turun hingga 0,081 $\mathrm{Nm}$. Ketika pada tegangan 10 volt di jumlah 1 magnet torsi yang dihasilkan sebesar 0,158 $\mathrm{Nm}$ dan pada jumlah 5 magnet torsi yang dihasilkan menurun hingga $0,115 \mathrm{Nm}$. Pada tegangan 12 volt torsi yang dihasilkan pada jumlah 1 magnet adalah sebesar 0,203 $\mathrm{Nm}$ sedangkan ketika magnet ditambahkan sampai jumlah 5 magnet torsinya menurun hingga $0,148 \mathrm{Nm}$.

\section{KESIMPULAN}

Berdasarkan hasil dan pembahasan data penelitian, diambil kesimpulan sebagai berikut:

1. Putaran motor listrik (RPM) tidak selamanya meningkat seiring bertambahnya medan magnet dan daya listrik input. Pada varisi medan magnet tertuntu dan daya listrik tertentu RPM motor listrik akan konstan.

2. Penambahan jumlah magnet menyebabkan penurunan daya listrik karena arus listrik menurun setiap bertambahnya medan magnet.

3. Efisensi daya listrik meningkat setiap kenaikan tegangan listrik power supply, efisiensi tertinggi pada tegangan 12 volt yaitu sebesar $83.366 \%$. Sedangkan penambahan medan magnet memperoleh nilai efisiensi berkisar antara $77.084 \%$ sampai $80.564 \%$, efisiensi yang tertinggi pada jumlah 1 magnet.

4. Setiap penambahan daya listrik input menyebabkan nilai torsi meningkat, karena arus listrik yang pada jangkar meningkat. Sedangkan setiap penambahan jumlah magnet nilai 
torsi motor listrik menurun, karena arus listrik menurun setiap penambahan medan magnet.

\section{DAFTAR PUSTAKA}

Adam, A.A. 2011. Perbandingan Konsumsi Daya Oleh Pengatur Kecepatan Motor Universal Yang Menggunakan Metode Modulasi Lebar Pulsa (PWM) Dan Metode Tahanan Depan. Jurnal Smartek. Vol 9, No. 1

Ananda, S.A.,Soewangsa, E.T. 2003. Studi Karakteristik Motor DC Penguat Luar Terhadap Posisi Sikat. Jurnal Teknik Elektro. Vol.3, No.1

Budiman, A., Asy'ari, H., Hakim, A.R. 2012. Desain Generator Magnet Permanen Untuk Sepeda Listrik. Jurnal Emiter. Vol 12, No 01.

Gunawan., Hindansyah, A., Ridwan.,Wagiyo., Agus S. 2000. Uji Fungsi Magnet Permanen Elastis P31B Pada Motor Listrik Arus Searah.

Jaya, T.S., Kusumawati, W.I., Puspasari, I. 2017. Analisis Perbandingan Magnet Neodymium Dan Magnet Ferrite Untuk Penerapan Generator. Jurnal CONES. Vol 6, No 1.

Kumalasari, R. 2019. Pengaruh Diameter Kumparan Armature Terhahdap Torsi Dan Daya Motor Listrik. Skrisi. Jurusan Teknik Mesin Fakultas Teknik Universitas Negeri Semarang

Pattiapon, D.R., Rikumahu, J. J., Jamlay, M. 2019. Penggunaan Motor Singkron Tiga Phasa Tipe Salient Pole Sebagai Generator Singkron. Jurnal simetrik. Vol.9, No.2.

Putra,D.H.Y., Dinzi, R. 2014. Studi Pengaturan Kecepatan Motor DC Shunt Dengan Metode Ward Leonard. Vol 6, No 1.
Raikhani, A. 2015. Studi Pengaruh Pembebanan Pada Motor DC Penguatan Shunt Terhadap Arus Stator. Jurnal Trisula LP2M Undar. Vol 1.

Rijono, Y. 1997. Dasar Teknik Tenaga Listrik Edisi Revisi. ANDI. Yogyakarta

Sa'dah, A. F., Fauzi, A., Juanda, B. 2017. Peramalan Penyediaan Dan Konsumsi Bahan Bakar Minyak Indonesia Dengan Model Sistem Dinamik. Jurnal Ekonomi dan Pembangunan Indonesia. Vol 17, No 2.

Saptono, H., Pramono, G.E., Al khindi, H. 2018. Analisi Daya Dan Kontrol Kecepatan Motor Pada Alat Bantu Las Rotary Positioner Table. Jurnal Ilmiah Teknik Mesin. Vol.4, No.1

Sunarti, M. 2018. Analisa Pengaturan Kecepatan Putaran Motor DC Penguat Dengan Menggunakan Thyristor. Jurnal Teknik Elektro. Vol 8, No.1

Susanto, E. 2017. Pengujian Unjuk Kerja Dan Pengukuran Parameter Motor Indukasi Satu Fasa. Skripsi. Program Studi Elektro Fakultas Teknik Universitas Muhamadiyah Surakarta

Suyanto, V. 2016. Analisis Performa Motor DC Feedback Tipe No. 63110 Di Laboratorium Listrik Dan Optimasi Kapal. Skripsi, Jurusan Teknik Perkapalan Fakultas Teknologi Kelautan Institut Teknologi Sepuluh Nopember Surabaya

Tipler, P.A. 2001. Fisika Untuk Sains Dan Teknik Edisi Ketiga. Airlangga.

Yuski, M.N., Hadi, W., Saleh, A. 2017. Rancang Bangun Jangkar Motor DC.

Vol 